\title{
PEMBINAAN IBU RUMAH TANGGA UNTUK MENDUKUNG PEREKONOMIAN KELUARGA MELALUI USAHA PEMBUATAN BROS
}

\author{
Hikmah", Ade Wilda Damanik \\ Manajemen, Universitas Putera Batam \\ email: hikmahupb@gmail.com
}

\begin{abstract}
Some housewives in Batam City do not work, relying solely on income from their husbands. During this time, housewives use their free time to socialize and have a good time with their neighbors without producing anything useful, so it's time to take advantage of these habits in order to produce something to support their family's economy. In order for income housewives to have new knowledge and abilities, crafting activities are carried out by using patchwork. This training is carried out to use patchwork to have more selling value such as hijab accessories. This training was carried out twice, which was given the understanding of housewives about the use of patchwork and then given the practice of learning by doing. In the implementation of the service carried out by practicing directly how to make a brooch with several models of patchwork. Aside from the guidance of making brooches from patchwork, researchers also provide assistance in managing financial management, so that in the future it can be used as a home business that can help support the family's economy. From the results of the evaluation at the service of the mothers, thousands of households have been able to make patchwork brooches with several variations and models
\end{abstract}

Keywords: development, housewife, brooch

\begin{abstract}
Abstrak: Sebagian ibu rumah tangga di Kota Batam tidak bekerja, hanya mengandalkan pendapatan dari suami. Agar ibu rumah tangga berpenghasilan dan memiliki pengetahuan dan kemampuan baru, maka dilakukan kegiatan pembuatan kerajinan dengan pemanfaatan kain perca. Pembinaan ini dilakukan untuk memanfaatkan kain perca lebih memiliki nilai jual seperti aksesoris jilbab. Pembinaan ini dilakukan sebanyak dua kali, dimana diberikan pemahaman Ibu rumah tangga tentang pemanfaatan kain perca dan selanjutnya diberikan praktek dengan metode learning by doing. Pada pelaksanaan pengabdian dilakukan dengan mempraktekkan langsung cara membuat bros dengan beberapa model dari kain perca. Selain dari bimbingan pembuatan bros dari kain perca peneliti juga memberikan pendampingan dalam pengelolaan manajemen keuangan, sehingga apabila dikemudian hari dapat dijadikan sebagai usaha rumahaan dapat meningkatkan membantu ekonomi keluarga. Dari hasil evaluasi saat pengabdian di para ibu -ibu rumah tangga sudah bisa membuat bros dari kain perca dengan beberapa variasi dan model.
\end{abstract}

Kata Kunci: Pembinaan, Ibu rumah tangga, Bros 
Jurdimas (Jurnal Pengabdian Kepada Masyarakat) Royal

Vol. 2 No. 1, Jan 2019, hlm. 1 - 6

ISSN 2614-7912 (Print)

DOI: https://doi.org/10.33330/jurdimas.v2i1.276

ISSN 2622-3813 (Online)

Available online at https://jurnal.stmikroyal.ac.id/index.php/jurdimas

\section{PENDAHULUAN}

Batam merupakan salah satu daerah di Indonesia yang temasuk kota Industri, sehingga menjadi tujuan bagi para pencari kerja. Namun, tiga tahun terakhir, banyak perusahaan yang tutup baik itu perusahaan Manufactur, shipyard maupun industi Minyak dan gas bumi. Dengan banyaknya perusahaan yang tidak beroperasi lagi maka, banyak masyarakat yang kehilangan mata pencaharian atau terkena PHK. Sehingga sumber penghasilan keluarga mereka menjadi berkurang. Berdasarkan data dari Dinas Tenaga Kerja (Disnkaer) Kota Batam jumlah pengangguran di Kota Batam tiga tahun terakhir ini (2014-2016) sebanyak 3.532 Orang dari 153 perusahaan yang tutup (Kerja, 2017).

Sebagian besar masyarakat di Kota Batam, ibu rumah tangga tidak bekerja, hanya mengandalkan pendapatan dari suami. Latar belakang pendidikan yang dimiliki oleh ibu rumah tangga di Perumahan Air Mas sebesar 75\% mereka adalah lulusan SLTA/sederjat dan masih usia produktif. Meskipun demikian, hal tersebut tidak menjamin keterbukaan pemikiran dalam memanfaatkan waktu dan pengembangan diri. Sehingga mereka tidak memiliki life skills tertentu. Ibu memiliki peranan penting dalam membentuk kualitas anak serta keluarganya. Ekonomi menjadi permasalahan yang utama dalam keluarga dengan rata rata perekonomian bergantung pada kepala keluarga (Setiyaningsih, 2016). Sehingga memiliki permasalahan kompleks yakni latar belakang ekonomi dan keterbuakaan pemikiran serta pemahaman dalam memanfaatkan waktu serta pengembangan kualitas diri sebagai seorang perempuan.

Selama ini Ibu rumah tangga mengunakan waktu luang mereka bersosialisasi dan beramah tamah dengan tetangga mereka tanpa menghasilkan sesuatu yang bermanfaat, maka saatnya memanfaatkan kebiasaan tersebut agar lebih menghasilkan sesuatu untuk menopang perekonomian keluarga mereka. Melimpahnya bahan baku untuk membuat kerajinan tangan, baik bahan baku baru maupun limbah atau sisa yang masih dapat digunakan, tidak akan menjadi sesuatu yang bernilai jual jika tidak ada sentuhan tangan kreatif dan ide kreatif (Mudjiyanti \& Kusbandiyah, 2016). Banyaknya literatur dalam pembuatan barang bekas atau limbah pun tidak akan mampu menumbuhkan atau memotivasi masyarakat, jika kita tidak membantu mereka menunjukkan bahwa diluar sana dibutuhkan orang-orang yang memiliki daya kreatifitas tinggi agar mampu memperbaiki taraf hidupnya. Agar ibu rumah tangga berpenghasilan memiliki pengetahuan dan kemampuan baru, maka perlu dilakukan kegiatan pemberian keterampilan pembuatan kerajinan dengan pemanfaatan kain perca. Pada daerah Batam ada beberapa industri konveksi dan yang dapat dimanfaatkan kain-kain bekas potongan yang ukurannya kecil-kecil. Sepintas kain sisa ini adalah kain yang tidak memiliki manfaat dan dibuang menjadi sampah, tapi sebenarnya sisa kain ini dapat dimanfaatkan sebagai kerajinan yang bernilai jual tinggi. Kain perca dapat dijadikan sebagai kerajianan tangan 
Available online at https://jurnal.stmikroyal.ac.id/index.php/jurdimas

seperti tas, sarung bantal, taplak meja, keset dan lain sebagainya.

Kain perca bisa berasal dari berbagai kain salah satunya adalah kain batik. Kain perca yang berasal dari kain batik bisa dibuat menjadi aksesoris yang unik dan cantik. Kain perca ini bisa diolah step by step dengan mudah menjadi gelang batik besar, bando batik, kalung bola-bola batik, sirkam rambut, jepit rambut, bros batik untuk kerudung kalung dan bros batik, cincin batik, ikat pinggang batik cokelat, bandana batik, hiasan batik untuk scarf, hiasan batik pada kerudung, bros dan ikat pinggang batik, hiasan batik untuk tas dan bros, hiasan topi, dan banyak lagi (Iva Hardiana, 2012), (Rahayu, 2014) Adapun permasalahan situasi yang telah dipaparkan di atas, maka dapat dilihat dan ditemukan mengenai permasalahan sebagai berikut: Banyaknya keluarga yang terkena PHK sehingga kehilangan sumber penghasilan, banyaknya waktu luang Ibu rumah tangga yang hanya digunakan untuk bersosialisasi dan beramah tamah dengan tetangga mereka tanpa menghasilkan sesuatu yang bermanfaat, Belum ada kegiatan pemanfaatan kain perca secara produktif, Pengetahuan dan wawasan Ibu rumah tangga dalam pemanfaatan Kain perca masih tebatas, Keterampilan Ibu Rumah tangga dalam kerajinan tangan masih rendah.

\section{METODE}

Pengabdian dilaksanakan di Perumahan Air Mas, Kel Sei Langkai, Sagulung Kota Batam. Metode untuk menyelesaikan masalah yang telah dirumuskan dalam pengabdian ini yaitu (1) Ceramah: Metode ini dipilih untuk menyampaikan teori dan konsep-konsep yang sangat prinsip dan penting untuk dimengerti serta dikuasai oleh peserta. Materi ini diberikan untuk mendorong peserta mengembangkan ketrampilan yang dimiliki menjadi usaha produktif. Materi pembelajaran pembuatan kerajinan tangan meliputi pengenalan karakteristik bahan, manfaat dari kain perca, dan teknik pembuatan aksesoris berupa bros. (2). Participatory learning:Participatory learning ditekankan pada kegiatan ini learning by doing melalui Latihan atau praktik.

Pada metode ini peserta akan mempraktekkan secara optimal semua teknik-teknik pembuatan aksesoris berbahan dasar kain perca dengan beberapa model dan desain. Untuk melihat sejauh mana pencapaian kegiatan dalam pengabdian ini dan sebagai perbaikan dan penyempurnaan untuk kegiatan pengabdian dimasa yang akan datang, peneliti akan melakukan evaluasi pelaksanaan kegiatan pengabdian yang meliputi antara lain: (1). Tahap sebelum kegiatan: Pengabdi akan melihat bagaimana hambatan atau kendala yang dihadapi oleh pengabdi baik saat observasi lokasi pengabdian, dukungan masyarakat setempat, dalam mengikuti kegiatan pengabdian ini, dan melakukan wawancara dengan masyarakat untuk menyimpulkan permasalahan. (2). Tahap saat pelaksanaan kegiatan: Pada tahapan ini peserta akan diberikan pemahaman tentang pemanfaatan kain perca yang bahan bakunya yang tidak perlu dibeli tetapi bisa menghasilkan pendapatan, dan terakhir diberikan demontrasi/praktek 
Available online at https://jurnal.stmikroyal.ac.id/index.php/jurdimas

cara pembuatan bros dari kain perca dengan beberapa model dan desain. (3). Tahap setelah kegiatan: Pada tahap ini, pengabdi akan melihat benda (Bros) yang dibuat jadi, evaluasi dilakukan untuk melihat disainnya, kreativitas, keserasian dan kombinasi warna serta penyelesaian.

\section{PEMBAHASAN}

Pengabdian yang dilakukan oleh pengabdi dalam kegiatan pelatihan yang diperuntukkan kepada Ibu-Ibu rumah tangga Di perumahan Air Mas Kecamatan Sagulung mendapat perhatian dan kesan yang baik oleh ibu-ibu rumah tangga yang mengikuti kegiatan.

Antutias peserta pengabdian terhadap kegiatan tersebut dapat dilihat dari adanya peserta yang berkenan mengikuti kegiatan yang dilakukan oleh pengabdi. pada saat pelaksanaan pembinaan para Ibu rumah tangga sangat tertarik di dalam melaksanakan praktik membuat bros dari kain perca dengan beberapa variasi model dan beberapa jenis kain.

Salah satu produk yang dapat dibuat dari kain pera yaitu bros. Untuk pembuatan bros bahan-bahan yang diperlukan seperti: Kain perca 60 x $30 \mathrm{~cm}$, Benang, Jarum, Mutiara imitasi, kain, Peniti, Gunting, Lem tembak, Kain keras.

Adapaun dalam pembuatan bros tersebut langkah-langkahnya adalah: Langkah 1:

1. Sambungkan kedua sisi yang mempunyai sisi lebar $30 \mathrm{~cm}$ dengan cara jelujur pada kedua sisi bagian kain dengan jarum disertai benang yang senada dengan warna kain agar terlihat cantik dan terkesan tidak asal-asalan, lakukan dengan hati-hati dan sebaik mungkin agar hasil akhirnya terlihat cantik.

2. Lipat ke bagian dalam agar sambungan pada cara kesatu tidak terlihat dari luar.

3. Lakukan kembali cara jelujur pada bagian luar agar dapat diserut yang akan di lakukan pada langkah 3

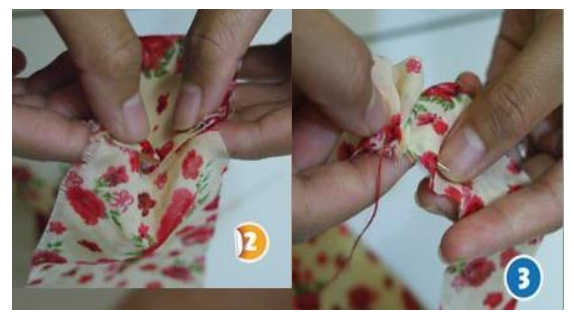

Langkah 2:

1. Setelah proses jelujur selesai dilakukan periksa kembali hasil jelujur dan pastikan tidak ada benang yang kusut agar memudahkan pada saat menyerut.

2. Berikutnya serut atau menarik benang agar bros yang kita buat mulai terlihat berbentuk bulat.

3. Lakukan dengan hati-hati agar hasil bulatan bros terlihat bulat dan rapih (jangan sampai benang tersebut putus sebelum mengunci jahitan setelah selesai serut).

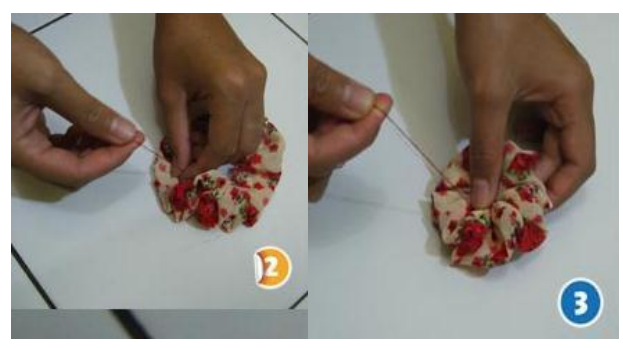

Langkah 3 :

1. Pasang manik-manik pada bagian tengah terlebih dahulu untuk memudahkan pemasangan manikmanik selanjutnya.

2. Pasang mutiara imitasi pada 
Jurdimas (Jurnal Pengabdian Kepada Masyarakat) Royal

Vol. 2 No. 1, Jan 2019, hlm. 1 - 6

ISSN 2614-7912 (Print)

DOI: https://doi.org/10.33330/jurdimas.v2i1.276

ISSN 2622-3813 (Online)

Available online at https://jurnal.stmikroyal.ac.id/index.php/jurdimas

benang dengan jumlah 6 buah dan lingkarkan kepada mutiara imitasi yang di pasang tadi di tengah dan lakukan engencangan agar mutiara imitasi diam pada tempatnya dan mengelilingi mutiara imitasi yang pertama di pasang di tengah.

Hasilnya akan menjadi seperti yang di gambar no 3 di bawah ini.

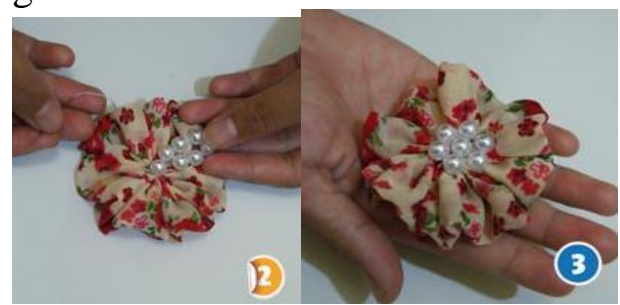

Langkah 4:

1. Sediakan kain keras berbentuk bulat dengan diameter yang dapat di sesuaikan dengan ukuran bros yang kita buat sebelumnya.

2. Lipat bagian tengah kain keras agar dapat membuat lubang untuk nanti dipasang penitik seperti pada gambar no 3 di bawah ini. 4 . Pasang penitik pada kain keras yang sudah di beri lubang pada langkah ke dua tadi.

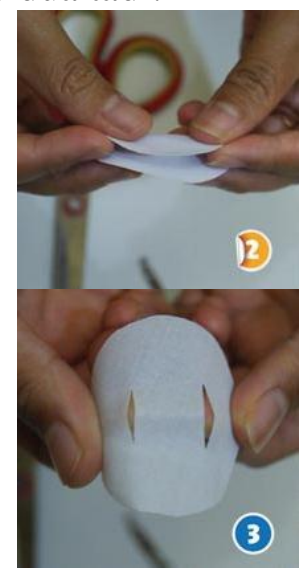

Langkah 5:

1. Beri lem pada bagian bawah kain keras untuk nanti di tempel pada bagian bawah bros yang anda buat tadi.

2. Pasangkan dengan hati-hati kain keras yang sudah di beri lem tadi dan pastikan terpasang pada bagian tengah agar terlihat cantik seperti pada gambar no 3 di bawah ini

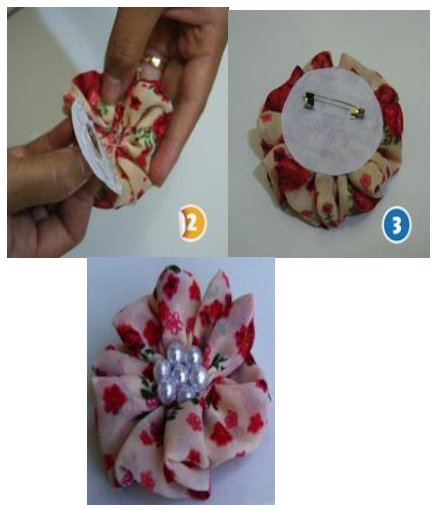

Dalam kegiatan pengabdian ini selain dari membuat Bros dari kain perca adalah menumbuhkan jiwa kewirausahaan bagi Para ibu-ibu rumah tangga dan memberikan pengetahuan tentang manajemen keuangan. Manajemen keuangan bukan hanya sekedar bagaimana manajemen uang kas. Tapi lebih dari itu, manajemen keuangan bagiamana para ibu rumah tangga mengelola kekayaan untuk menghasilkan keuntungan dan memanfaatkan sumber-sumber modal untuk membiayi rumah tangga dan membuka usaha kelak. Meski serderhana, Ibu rumah tangga pun perlu menerapkan prinsip-prinsip manajemen keuangan.

Setelah dilakukan pelatihanpelatihan pada Ibu-ibu rumah tangga sudah bisa membuat bros dengan beberapa variasi warna dan model. Dengan keterampilan yang dimiliki oleh para Ibu rumah tangga maka nantinya bisa membantu meningkatkan pendapatan keluarga melalui pembuatan bros yang 
Jurdimas (Jurnal Pengabdian Kepada Masyarakat) Royal

Vol. 2 No. 1, Jan 2019, hlm. 1 - 6

DOI: https://doi.org/10.33330/jurdimas.v2i1.276

ISSN 2622-3813 (Online)

Available online at https://jurnal.stmikroyal.ac.id/index.php/jurdimas

nantinya bisa dijadikan sebagai penunjang ekonomi keluarga.

\section{SIMPULAN}

Pembinaan yang dilakukan di Perumahan Air Mas berjalan dengan lancar berkat dukungan dari masyarakat. Dalam peningkatan ekonomi keluarga tidak selamanya harus mengunakan alat dan bahan yang mahal, tapi bagaimana memanfaatkan barang-barang yang sudah tidak pakai untuk menghasilkan sesuatu yang bermanfaat dan memiliki nilai ekonomi. Melalui pembuatan bros dari kain perca diharapkan nantinya akan memunculkan ide kreativitas dari para ibu rumah tangga untuk lebih berkreasi kedepannya.

\section{UCAPAN TERIMAKASIH}

Kegiatan pengabdian kepada masyarakat ini tentunya, tak terlepas dari bantuan berbagai pihak, untuk itu ucapan terima kasih kami sampaikan kepada:

LPPM Universitas Putera batam sebagai penyelenggara kegiatan.

1. Bapak RT 001 Air Mas atas dukungannya dalam pelaksanaan pengabdian.

2. Ibu Tri sebagai fasilisator dalam penyelenggaraan pengabdian.

3. Ibu -Ibu Perumahan Air Mas

4. Tim pengabdian kepada masyarakat yang telah bekerjasama dengan baik, sehingga kegiatan dapat berjalan lancer.

\section{DAFTAR PUSTAKA}

Iva Hardiana. (2012). Terampil
Membuat Aksesoris Cantik dari

Kain Batik. Jakarta: PT. Gramedia Pusaka Utama.

Kerja, D. T. (2017). Dinas Tenaga kerja.

Mudjiyanti, R., \& Kusbandiyah, A. (2016). Kain Perca Sebangai Penyangga Ekonomi Rumah tangga. Prosiding Seminar Nasional Penelitian Dan PKM Sosial, Ekonomi Dan Humaniora.

Rahayu. (2014). Bos dari bunga pita (1st ed.). Jakarta: Tiara Aksara.

Setiyaningsih, L. A. (2016). Pelatihan handycraft Talenan Vintage dan Cyber Promotion Untuk ibu Rumah Tangga berpengahsilan rendah Kelurahan Kasin Kota malang. Jurnal ABDIMAS Unmer Malang, 1, 1-3. 